\title{
Kjønnssegregering og kvinners handlingsvalg
}

\begin{abstract}
Artikkelen diskuterer hvordan saudiske kvinner håndterer skrevne og uskrevne normer og regler for atferd i offentlige rom. Analysen antyder at kvinner finner kreative handlingsmuligheter til tross for klare atferdsregler. I tillegg diskuteres betydningen av sosiale arenaer og klassetilhørighet for handlingsvalg.
\end{abstract}

Av Tine Kjeldstadli, master fra Sosialantropologisk institutt ved Universitetet i Oslo med oppgaven "Kvinner i Riyadh. En studie om muligheter og begrensninger for kvinners handlingsvalg".

I RIYADH, SAUDI-ARABIA, SOM I ALLE SAMFUNN, forventes det at menn og kvinner oppfører seg på bestemte måter. I Riyadh må alle kvinner dekke seg til i det offentlige i sorte, lange "frakker» (abayaer) ${ }^{1}$, og det forventes at kvinner behersker stemmeleie og kroppsbevegelser i settinger der ubeslektede menn er til stede. Videre er det klare regler for menn og kvinners bruk av landskap og arenaer, som i Riyadh ofte er inndelt i egne områder for kvinner og menn. Men til tross for slike sterke sosiale konvensjoner, er det stor variasjon i hvordan mennesker handler i praksis.

Denne artikkelen belyser segregeringspraksisen i Riyadh med hovedvekt på oppholdssted og bruk av rom. Med utgangspunkt i et feltarbeid fra Riyadh i 2010, spør jeg hvordan kvinner håndterer skrevne og uskrevne normer og regler ved arenaer hvor både kvinner og menn har tilgang (mukhtalat). Nærmere bestemt tar artikkelen utgangspunkt i segregeringspraksis ved to ulike fritidsarenaer i Riyadh. Artikkelen viser hvordan mennesker finner kreative handlingsmuligheter til tross for klare regler for atferd. Videre analyseres ulike arenaer, sosial kontroll og klassetilhørighet, som bidrar til en variert segregeringspraksis. Jeg argumenterer for at kvinners handlingsmuligheter påvirkes av en interseksjonalitet, et begrep som understreker et samspill mellom sosiale kategorier som kjønn, rase, klasse, alder og etnisitet. ${ }^{2}$ I artikkelen ønsker jeg særlig å vise hvordan kvinners handlingsmuligheter samspiller med klassetilhørighet og sosial kontroll.

\section{Metodiske tilnærminger}

Det finnes få antropologiske studier fra SaudiArabia. Stort sett er de eksisterende antropologiske studiene gjort av saudiske antropologer eller av forskere som i liten grad har basert seg på deltakende observasjon. ${ }^{3}$ I 2010 fikk jeg mulighet til å gjøre et feltarbeid i Riyadh i seks måneder, som en del av mitt masterstudium i sosialantropologi. Felt-

Abaya-reklame fra klesbutikken Aab. I Saudi-Arabias hovedstad Riyadh er klesplagget påbudt for alle kvinner. 


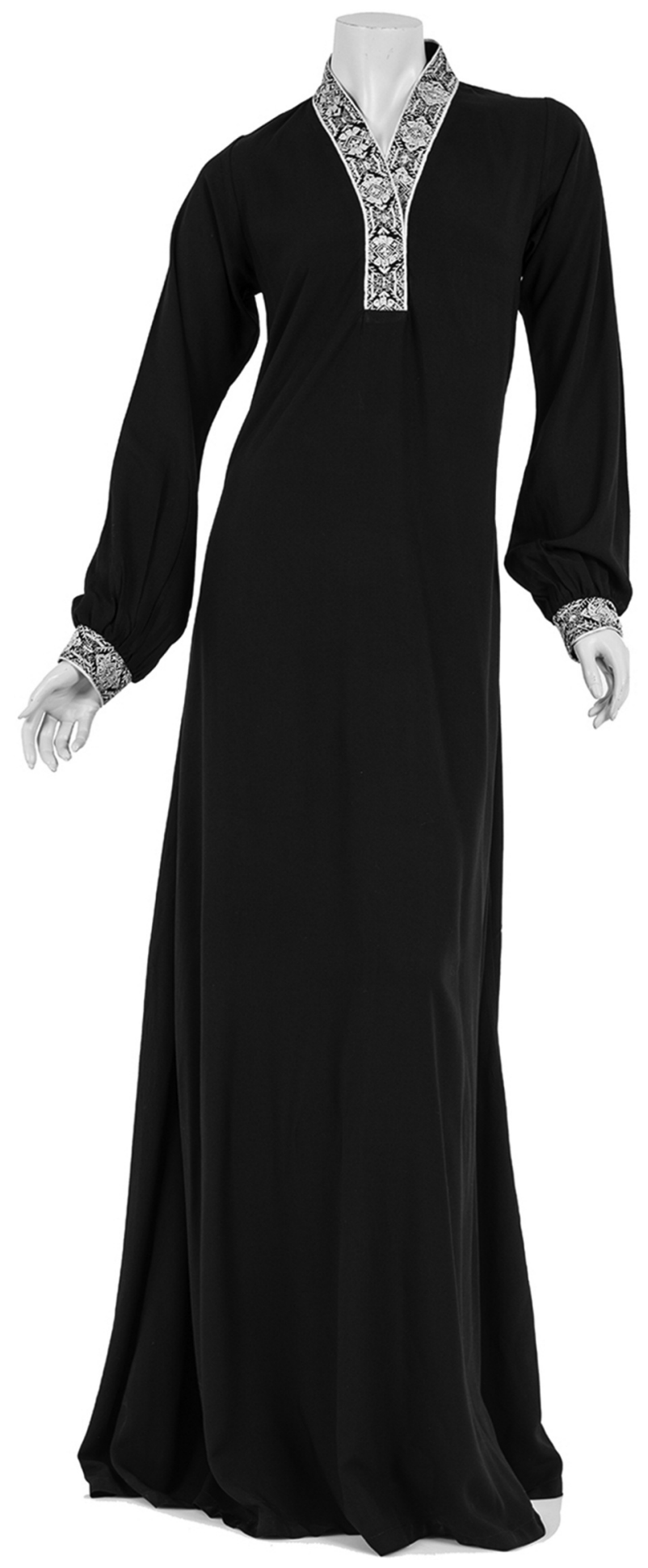

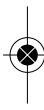




\section{TINE KJELDSTADLI}

arbeidet var en gyllen mulighet til å gjøre et lengre studie $i$ et område som var lite utforsket av antropologer.

Jeg gjorde et multisited fieldwork på grunn av feltets iboende begrensninger. Metoden innebærer å gå utenfor én lokalitet for å fokusere på sirkulasjon av blant annet mennesker, kulturelle objekter og konflikter. ${ }^{4}$ Julie Billaud beskriver dette som en uopportunistisk» fremgangsmåte, noe hun selv var avhengig av da hun gjorde et feltarbeid i krigsherjede Kabul. Opportunismen innebærer å navigere ut fra de muligheter som oppstår gjennom møter og tilfeldige kontakter. ${ }^{5}$ I Riyadh innebar det å besøke kvinner som kontaktet meg, eller som jeg hadde kontaktet selv. I løpet av feltarbeidet møtte jeg omtrent 20-25 kvinner en eller flere ganger. Kvinnene var i aldersgruppen 15-6o år, og kom stort sett kom de fra den saudiske middelklassen. ${ }^{6}$ Av disse tilbrakte jeg spesielt mye tid med fire-fem kvinner i aldersgruppen 20-30 år. Sammen pratet vi om deres interesser, drømmer, ambisjoner og bekymringer, i tillegg til å gjøre ulike aktiviteter sammen.

I løpet av feltarbeidet anvendte jeg deltakende observasjon, dernest semi-strukturerte intervjuer og direkte observasjon, i tillegg til å innhente data fra skriftlige kilder.

Anonymisering har vært en viktig prioritering under feltarbeidet og i den senere skriveprosessen. Både navn, alder, bosted og familieinformasjon er endret av hensyn til informantene. Videre har jeg endret enkelte trekk ved de empiriske eksemplene.

\section{Segregeringspraksis i Riyadh}

I Riyadh berører kjønnssegregeringen nærmest ethvert aspekt ved det sosiale liv. Segregeringen innebærer en arbeidsdeling mellom kjønn, klare regler for oppholdssted og bruk av rom, en rekke forventninger til kvinner og menns væremåter og handlinger, og ikke minst rutiner og forskrifter om klesdrakter.7 Kjønnssegregeringen kan helt forenklet forstås i sammenheng med forestillinger om seksualitet, som sier at menn og kvinner må holdes adskilt fordi menn er svake overfor kvinners tiltrekningskraft. ${ }^{8}$

Saudi-Arabia er ett av få land hvor segregeringspraksisen opprettholdes av det religiøse politiet, også kjent som muttawa. ${ }^{9}$ Med følge av en politimann har moralens voktere autoritet til å arrestere borgere og utlendinger for usømmelig atferd. En form for usømmelig atferd er situasjoner hvor ubeslektede menn og kvinner omgås alene, en situasjon som heter khulwa på arabisk. ${ }^{10}$ Khulwa er en stor synd i Saudi-Arabia, og partene risikerer strenge straffer dersom man oppdages.

I Riyadh preges hushold, og de fleste offentlige arenaer som restauranter, kafeer, treningssentre, skoler og statlige institusjoner, av segregeringen. Imidlertid er de offentlige arenaene underlagt forskjellige grader av segregering, og de får flere uttrykk som rent segregerte sfærer og blandede arenaer (mukhtalat). Et eksempel på sistnevnte er kjøpesentre, som ikke eksisterte før 1979. ${ }^{11}$ Kjøpesentrene er moderne og tilbyr de siste trendene fra det internasjonale markedet. Samtidig er de en hybrid arena hvor det moderne og det tradisjonelle glir over i hverandre. Butikkenes åpningstider reguleres av en hellig og profan tid som făr sitt uttrykk ved bønnerop (adhan). Adhan annonseres over store høytalere på kjøpesentrene, og under bønnen stenger samtlige butikker og kafeer. Kjøpesentrene er utbygd i tråd med segregeringsprinsippet med hensikt om å holde ubeslektede menn og kvinner fra hverandre. De er forbeholdt familier og kvinner, og i 2010 hadde ikke enslige menn i utgangspunktet adgang. I 2010 fikk segregeringen også sitt uttrykk ved at 
kvinner ikke kunne jobbe i butikker hvor både menn og kvinner hadde tilgang. Disse butikkene ble betjent av mannlige fremmedarbeidere fra land som Bangladesh, India, Pakistan og Filippinene. Konservative religiøse ledere har lenge protestert mot at kvinner jobber i butikker, fordi kvinnene da kan komme i kontakt med ubeslektede menn. Butikkeiere protesterte på sin side mot å ansette saudiske kvinner, fordi det ville innebære høyere lønnskostnader enn ved bruk av fremmedarbeidere. ${ }^{12}$ At menn arbeidet $i$ butikker for kvinner gjorde at segregeringspraksisen ble underlagt noen tvetydigheter. Det ble et paradoks at undertøysbutikker ble betjent av menn som selger de mest intime kvinneplagg. Mannlige fremmedarbeidere i en undertøysbutikk kan sees på som en matter out of place. ${ }^{13}$ Samtidig betraktes disse mennene som annenrangs kjønn, og ikke som en direkte trussel overfor kvinner. ${ }^{14}$ Flere kvinner har likevel rast mot denne praksisen og myndighetene var lenge innforstått med problematikken knyttet til undertøysbutikkene. I 2012 endret myndighetene praksisen slik at kvinnelige ansatte nå jobber i undertøysbutikker.

Kjønnssegregeringen legger føringer og begrensninger på bruk av landskapet og fysiske strukturer i Riyadh. Eric Wolf definerer taktisk/organiserende makt som "power to control the setting in which people may show forth their potentialities and interact with others». ${ }^{15}$ Arkitektur kan fungere som en form for organiserende makt, som gjør noen atferdsmønstre gjennomførbare og andre mindre realiserbare. Kjøpesentrenes utforming begrenser hvem som har tilgang, samt hvor og hvordan de kan bevege seg. Arkitekturen er med andre ord strukturert i tråd med kjønnssegregeringen, noe som også kommer til syne ved at det ikke finnes prøverom i klesbutikker. ${ }^{16}$
Dersom kvinner ønsker å prøve et klesplagg, må de prøve det hjemme og returnere det hvis det ikke passer. En annen mulighet er å benytte avgrensede områder ved toalettene hvor det er mulig for kvinner å prøve klær. Hvis plagget ikke passer, returneres det i butikken, og et nytt plagg tas eventuelt med for å prøves. For å få pengene tilbake, må telefonnummer og navn gis til den mannlige ansatte bak kassen.

Til tross for at segregeringen fører til klare regler for bruk av rom og er en form for organiserende makt, er det likevel viktig å understreke at individer handler aktivt i møte med denne organiseringen. Michel de Certeau be-

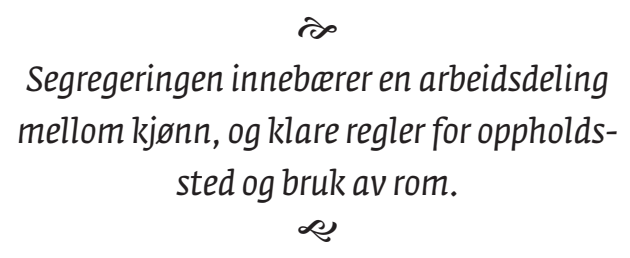

toner hvordan sosiale normer og regler kan være gjenstand for manipulasjon av utøvere som ikke har produsert dem. ${ }^{17,18}$ Han beskriver dette som tactics, som han definerer som «the art of the weak». Tactics fremhever hvordan mennesker skaper et handlingsfelt for seg selv i møte med en påtvunget sosial orden, noe eksempelet nedenfor illustrerer.

En ettermiddag dro jeg sammen ei jente i 20-årene, Farah, til et kjøpesenter i Riyadh. Varmen lå som et lokk over ørkenbyen, og hun skulle kjøpe en bikini for å ta en dukkert i familiens svømmebasseng om kvelden. Vi tok derfor turen til en av de moderne motebutikkene hvor hun fant en bikini. Farah ville prøve bikinien i den avgrensede prøveavdelingen, men da vi skulle betale sa den mannlige kassereren at det ikke var mulig à bytte bikinien selv om hun bare tok med plagget ut av butikken for å prøve den ved senterets 
separate prøveseksjon. Farah ble opprørt, men mannen sto bestemt på sitt. Hun ble dermed usikker på størrelsen nå som hun ikke kunne prøve plagget. Kanskje hun skulle ta en annen størrelse, mumlet hun lavt til seg selv, samtidig som vi gikk tilbake til bikiniene. Jeg foreslo at hun kunne dra bikinitrusen over buksen. Hun hadde tross alt abayaen på, og kunne prøve den uten å vekke for mye oppmerksomhet, mente jeg.

Farah så dumt på meg: «Try it on? Are you serious?»

"Yeah, why not? I will stand in front of you, so nobody can see while you try it on", svarte jeg.

Farah lot seg overbevise, og kneppet opp abayaen. «I can't believe I am doing this!», sa Farah og tittet ned på bikinitrusen som var trukket utenpå buksen. Hun lo lavt med et litt usikkert drag i ansiktet. Selv om det var få i butikken, brøt hun likevel normen om tildekning i det offentlige rom. Særlig med tanke på at hun prøvde en bikinitruse som er et intimt klesplagg, og med abayaen åpen eksponerte hun hele kroppen for mulig innsyn. Bikiniene var plassert like ved butikkens inngang, og senterets kunder gikk forbi utenfor. "It fits», konkluderte Farah, før hun tok av underdelen og betalte i kassen.

Kjønnssegregeringen legger føringer på handlinger, men samtidig agerer individer likevel kreativt i møte med disse begrensningene. Arlene Macleod betoner at kvinner, selv som underordnede aktører, både kan akseptere, tilpasse, ignorere og motsette seg den sosiale orden som er påtvunget dem. ${ }^{19}$ En slik tilnærming bidrar til å tegne et bilde av kvinner som noe annet enn passive ofre. Kvinner skaper seg handlingsrom til tross for ulike restriksjoner som begrenser deres handlingsmuligheter. At Farah prøvde bikinitrusen midt i butikken kan sees på som en tactic. En kan hevde at overtredelsen oppsto via meg, som bidro til å skape denne scenen. Mot dette kan man si at til tross for at jeg oppmuntret Farah til å prøve bikinitrusen, valgte hun selv å prøve den til slutt. For å bruke Lila Abu Lughods uttrykk mobile homes om den afghanske burkaen, ${ }^{20}$ kan abayaen i denne sammenheng betraktes som et mobilt prøverom.

Hvilken betydning har modernisering og konsum for kjønnssegregering i Saudi-Arabia? Med den økonomiske veksten som fulgte oljeboomen på 7o-tallet utviklet Riyadh seg raskt med konstruksjoner av bygninger, kjøpesentre og annen infrastruktur. Med økonomisk vekst ble også den saudiske befolkningen mer kjøpesterk, og i dag preger det internasjonale motebildet klesplagg blant den yngre saudiske befolkningen. I sin analyse av urbane kvinner i Riyadh viser Amélie Le Renard hvordan kvinners overtredelse av normer og regler bidrar til en reforhandling av normer og forventet atferd i det offentlige. ${ }^{21}$ Le Renard viser hvordan flere kvinner er mer likegyldige til religiøse lærdes fortolkning av anstendig tildekning i det offentlige. Slike endringer må forstås i sammenheng med økt konsum, men også ut fra myndighetenes fokus på reform i 2001, hvor også kvinners rettigheter og rolle i samfunnet ble satt på agendaen..$^{22}$ Religiøst skolerte i Saudi-Arabia har utstedt domsavsigelser (fatwaer) om hvordan kvinner bør dekke seg til i det offentlig. Her vises det til at abayaens materiale skal være tykt, svart og løssittende, slik at konturen av kroppen ikke er synlig. Videre skal abayen skal helst plasseres på toppen av hodet, for å unngå at skuldrene fremheves. Den bør ikke være utsmykket med dekorasjoner, symboler eller skrift. ${ }^{23}$ Det religiøse politiet har som formål å blant annet

I 2012 endret myndighetene lovverket som sa at bare menn kunne arbeide i butikker. Etter mange protester fikk saudiske kvinner lov til å arbeide i butikker som selger dameundertøy. 


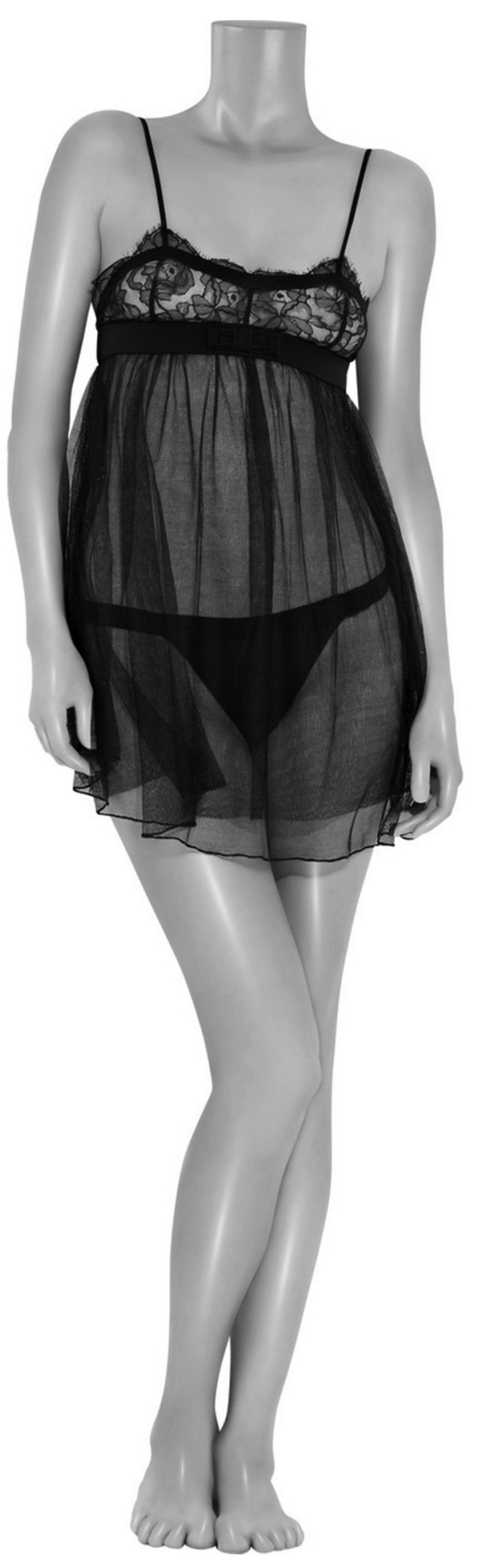


TINE KJELDSTADLI

kontrollere overholdelse av kjønnssegregeringen og anstendig tildekning. Da jeg var i Riyadh, så jeg selv hvordan det religiøse politiet hadde oppsøkt abaya-butikker, og krevd at "usømmelige» abayaer ble fjernet fra sortimentet. Imidlertid velger svært mange kvinner abayer som ikke stemmer overens med den religiøse fortolkningen. I Riyadh bruker alle kvinner sorte abayaer, men det finnes variasjoner. Mange kvinner har abayaer både til hverdagsbruk, og finere varianter til spesielle anledninger som fest og bryllup. Abayaene dekoreres ofte med mønster og farger langs ermene som gjør at enhver abaya blir unik. Den enkle svarte modellen kommer med andre ord i utallige versjoner som preges av motetrender, anledning, sesong og årstid. Men til tross for at abayaen også preges av motetrender, bryter ikke plagget helt med den religiøse forståelsen av anstendig tildekning. Abayaen forblir svart og lang, selv om den utsmykkes med dekorasjoner og tilbehør. Abaya som moteikon bryter derfor kun delvis med den hegemoniske orden, men erstatter aldri det primære formålet. ${ }^{24}$

Segregeringens virkemiddel: Sosial kontroll Som nevnt var kjøpesentrene forbeholdt familier og kvinner i 2010. Dersom en enslig mann ble oppdaget, kunne han risikere å eskorteres ut av senteret, noe jeg bevitnet en sen sommerkveld i juli ved Riyadh Gallery. Dette kjøpesentret består av en rekke internasjonale butikkjeder $\mathrm{i}$ to etasjer som primært selger klær til barn og kvinner. I tredje etasje ligger spisesteder på rekke og rad, og en tilhørende spiseseksjon med 200-300 bord i tillegg til et enormt lekesenter. Det var betydelig flere besøkende enn vanlig denne sommerkvelden, noe som blant annet skyldtes at sommerferien hadde startet. På veggen langs taket i tredje etasje hang en enorm tv-skjerm, som vanligvis viste reklame for kjøpesenterets butikker. Imidlertid var det noe annet enn reklame som engasjerte de flere hundre besøkende denne kvelden, nemlig VM-finalen i fotball mellom Nederland og Spania. Både menn og kvinner i alle tre etasjer fulgte ivrig med på den store skjermen. Med jevne mellomrom brøt

\section{Riyadh er sosiale konvensjoner mer}

fleksible blant eliten og i situasjoner hvor sosial kontroll er begrenset.

mengden ut i applaus og tilrop i tråd med spillernes prestasjon i Sør-Afrika. "Look how everybody has forgotten about the segregation", kommenterte min saudiske venninne da vi stilte oss bak en guttegjeng i slutten av tenårene. Jeg la merke til hvordan en av guttene vekslet mellom å følge med på kampen og kikke på ei ung jente i sort abaya og slør (tarha) som sto siden av ham.

Midtveis i finalen, kom plutselig to muttawa og en politimann sakte opp rulletrappen til tredje etasje. Det var første gang jeg så muttawa sammen en politimann, så vi bestemte oss for å følge etter dem på en viss avstand.

Stemningen endret seg fullstendig etter at det lille følget kom opp rulletrappen. Trolig hadde de beordret at storskjermen skulle skrus av, fordi den ble svart. At skjermen ble skrudd av satte sitt preg på tilskuerne som forsto at noe var på ferde, og den urolige stemningen spredde seg raskt blant mengden. Kvinner satte seg raskt ned i egne arenaer vekk fra ubeslektede menn, og unge gutter skyndte seg mot de andre rulletrappene for å komme seg ut. Disse guttene hadde krøllete, moteriktig afro, og buksene var dratt litt ned. De er av særlig interesse for muttawaen, fordi denne klesstilen 
etter deres syn ikke er forenlig med islamske prinsipper.

Det lille følget på tre spaserte rolig rundt blant mengden, og i dag var målgruppen menn uten kvinnelig følge. Med jevne mellomrom stoppet de gutter og menn, og spurte hvor deres kvinnelige familiemedlemmer var. I ett tilfelle gikk moralens voktere bort til ei jente i seksårsalderen, som måtte bekrefte at en mann var beslektet med hennes familie. Gradvis økte rekken med menn i hvite thobes ${ }^{25}$ fra to til seks, og de enslige «lovbryterne» ble fulgt ut av kjøpesenteret. Like raskt som stemningen ble lavmælt, tok den seg opp med en gang muttawaen forlot tredje etasje. Kampen ble satt på, og tilskuerne fortsatte å følge med på den avgjørende finalen.

For å oppsummere er kjøpesentrene i Riyadh regulert i tråd med segregeringsideologien. Det foreligger klare regler for bruk av den fysiske strukturen. Det er egne køer for menn og kvinner, og det finnes ingen prøverom i de delene av kjøpesentrene der menn har tilgang. Videre kontrollerer muttawaen at segregeringen opprettholdes. Samtidig er kjøpesentre en arena hvor det tradisjonelle møter det moderne som konsum, mote og internasjonale impulser. Som en kontrast til segregeringspraksisen ved en relativt åpen arena, vil jeg i det følgende diskutere segregering ved en mer avgrenset arena. Her vil jeg særlig belyse betydningen av klassetilhørighet for praktisering av kjønnssegregering.

\section{En sportsturnering}

Våren 2010 dro jeg og en gruppe saudiske jenter til en bilbane som ligger omtrent $85 \mathrm{~km}$ utenfor Riyadh for å se et billøp. Samtlige deltakere i turneringen var menn, og flere kommer fra høyere sosiale sjikt hvorav saudiske prinser og menn fra den mektige bin Laden-familien kan tjene som eksempler. Med andre ord var dette et arrangement med representanter fra de høyere sosiale lag.

Jeg ankom boligen til Nawaar og hennes familie en tidlig torsdagsformiddag før billøpet. I likhet med andre saudiske hushold beskyttes boligen av høye murer, som skjuler både svømmebasseng, trampoline, en stor hage og andre fritidsobjekter. Venninnen Farah hadde allerede kommet, og begge jentene var i godt humør da jeg banket på døren til Nawaars pikeværelse. Vi utvekslet klemmer, og jeg slo meg ned på sengen sammen med Farah. Nawaar satte seg ned foran et lite sminkebord for å ta en siste titt $i$ speilet før vi skulle reise. Nawaar var ikledd jeans og hvit topp, og hadde fargerike sko på føttene. Hun hadde lagt på en lett sminke, og det lange håret var rettet ut. Hun forklarte at hun ville se bra ut, fordi det kom til å være mange besøkende ved bilbanen i dag. Nawaar hadde derfor fikset seg litt ekstra, og da vi ankom billøpet viste det seg at hun ikke var den eneste som pyntet seg. Farah var ikledd en løssittende grå t-skjorte, lyse jeans og beige tursko.

Da vi forlot husholdet, tok vi på oss abayaer og tarha, og gikk ut til Nawaars mannlige sjåfør i bilen utenfor. Selve bilturen tok om lag en time gjennom det enorme ørkenlandskapet utenfor Riyadh.

Det første bruddet jeg la merke til da vi ankom bilbanen, var den vestlige musikken som durte ut fra store høyttalere. I Riyadh er både kinoer, teater og konserter forbudte aktiviteter, så musikk i det offentlige rom er ikke vanlig kost.

Fra en enorm tribune med beskyttende tak mot den sterke solen hadde vi god utsikt over bilbanen og ubegrenset tilgang på gratis brus og små smørbrød. Omtrent 20-30 mennesker samlet seg ute på tribunen da billøpene startet. 


\section{TINE KJELDSTADLI}

På tribunen og ved bilbanen generelt var det ingen som brydde seg om segregering. Her satt ubeslektede gutter og jenter siden av hverandre og så bilene passere i høyt tempo. På forhånd, på pikeværelset, hadde Nawaar og Farah snakket om at det var lov å ta av seg abayaen, og begge virket positivt innstilt til å legge fra seg den svarte kappen. Imidlertid valgte kun Farah å ta den av, og hun var den eneste jenta som tok den av på tribunen. Nawaar, som hadde pyntet seg for anledningen, beholdt den på. Et fåtall kvinner og menn stirret da Farah lot abayaen falle, men hun brydde seg ikke det minste. Selv følte jeg meg mer komfortabel med abayaen på, så jeg spurte Farah hvorfor hun valgte å ta den av. Hun begrunnet det med at dette var et internasjonalt arrangement, og her var det andre normer og regler som gjaldt. Kanskje hadde hun rett. Ingen kom bort til oss og ba henne ta abayaen på igjen.

Etter et par timer bestemte jentene seg for å kjøre go-cart, noe som vekket min interesse med tanke på forbudet i Riyadh om at kvinner kan kjøre bil. Vi samlet derfor reisefølget, som nå var på åtte-ti stykker, og forlot tribunen på vei mot den lille go-cartbanen. Vi slo oss ned i en liten hall og ventet på at andre menn og kvinner skulle kjøre først. Et nytt brudd med forventet atferd i det offentlige kom til syne da jentene skulle kjøre go-cart. For det første var det i seg selv uvanlig å tenke seg en kvinne bak et ratt i Riyadh. I tillegg trosset samtlige jenter påbudet om å dekke seg til foran ubeslektede menn da de kjørte go-cart uten abaya. Den lille gruppen tok av seg abayen før de gikk ut på banen. Noen gitt ut på banen i vestlige klær uten tildekket hår. Andre kompenserte med å dekke seg til moderat før de skulle kjøre, som ved å ta på en løssittende skjorte, og en stor hatt som dekket alt håret. Andre jenter gikk ut på banen i ermeløse topper og oppbrettede bukser, mens musikken, som ellers er forbudt i offentlige rom, durte ut av høyttalerne.

Etter å ha tatt bilder av reisefølget i gocartbiler, slo jeg meg ned ved siden av Haifa på 17 år som hadde valgt å slappe av inne. Hun hadde flyttet tilbake fra England til SaudiArabia da hun var 11 år. Haifa var oppgitt over forholdene i Riyadh, og vi kom inn på det at jenter pynter seg til billøpet.

"Why do you think Saudi girls dress up at a car race?», sa Haifa oppgitt, før hun besvarte spørsmålet selv:

"I believe half of them aren't even here for the race. But they try to look their best when they have the chance to sit in a mixed area. Even if a girl won't speak to a guy, she will still want him to look at her. In Norway, let's say, there is no segregation since it's mixed everywhere. So Norwegian women don't have to dress up to go to a football game. Mixed areas are uncommon in Riyadh, so women take whatever chance they get. I also believe they behave like this because of the upbringing in Saudi. If your parents don't get you used to both female and male friends being part of your life, then you are going to look at the male species as a whole different thing. It's going to be just about the attraction then. So I think dressing up is mainly about getting attention.»

Med andre ord kan det at jenter pynter seg sees på som en tactic for å vise seg fram for gutter, noe som ellers er vanskelig å gjøre i Riyadh. Samtidig handler det nok like mye om en anledning for å pynte seg generelt, og ikke nødvendigvis en ren strategisk avgjørelse for å få gutters oppmerksomhet. ${ }^{26}$

\section{Sportsturneringens temporalitet}

Hvorfor var mange begrensninger på kvinners atferd fraværende ved denne sportsturneringen? Sportsarenaen kan forstås som en gråsone der sosiale konvensjoner er diffuse. Victor Turner hevder at kulturelle forestillinger 
som ritualer, karneval, festivaler og konkurranser ofte kjennetegnes av en temporalitet hvor «for a while almost anything goes: taboos are lifted, fantasies are enacted, the low are exalted and the mighty abased, indicative mood is reversed". ${ }^{27}$ Turner hevder videre at "the great genres, ritual, carnival, drama, spectacle, possess in common a temporal structure [...] and allows a place for spontaneous invention and improvisation in the course of any given performance. $\aleph^{28}$

En slik temporalitet ved sportsturneringen fikk flere uttrykk. Dette var et arrangement som ble organisert et stykke utenfor Riyadh, vekk fra sosial kontroll og samfunnet for øvrig. Dessuten var de hverdagslige sosiokulturelle konvensjoner diffuse ved denne arenaen. Kvinner og jenter kunne ta av abayaen foran fremmede menn uten at det førte til reaksjoner eller sanksjoner. I tillegg til å ta av seg abayaen, kjørte jentene go-cart, noe som står i kontrast til forbudet mot å kjøre bil i Riyadh. Atmosfæren ved billøpet kan på mange måter sammenliknes med en karnevalatmosfære hvor «the carnival ambience [...] allows for the relaxation of interaction norms which reign in the more private segments of life, providing a fertile ground for the emergent expression of new social identities. $1^{29}$ Sagt på en annen måte, var dette en legitim arena for jentene å vise en annen side ved seg selv.

\section{Billøpet som en eksklusiv affære}

Også økonomisk og politisk maktutøvelse må tas med i en forståelse av den avslappede segregeringen. Arrangementet bestod hovedsakelig av deltakere fra den saudiske makteliten, som er eksklusiv og elitistisk. Sportsturneringen, med sine deltakere fra prominente saudiske og arabiske familier, markerte en grense mellom de som inkluderes og de som utelukkes. ${ }^{30}$ Bare medlemmer av bilbanen har tilgang til fasilitetene. Dermed har ikke alle samme tilgang til arrangementet, og å være publikum kan sees på som en form for innlemmelse i makteliten.

Med andre ord var sportsturneringen et lukket arrangement for samfunnets øvre elite. Arrangementet hadde noen temporale trekk, men betydningen av sosial status og klasse var

\section{so \\ Andrejenter gikk ut pågo-cartbanen i ermeløse topper og oppbrettede bukser mens musikken durte ut av høyttalerne. $\infty$}

vel så avgjørende for segregeringspraksisen ved denne arenaen. Sagt på en annen måte er eliten ganske distansert fra den strenge religiøse segregeringspraksisen. I Saudi-Arabia beskrives sosial kapital som wasta, det vil si de sosiale tilknytningene et individ kan trekke på i hverdagen. En person med wasta kan slippe unna bøter og andre straffer ved å ha de riktige kontaktene. Den saudiske kongefamilien har mer wasta enn noen andre sosiale sjikt, og deres makt overgår den religiøse ledelsens autoritet. Det at en prominent prins er administrerende direktør for bilbanen, begrenser det religiøse politiets makt ved arenaen. Fraværet av sosial kontroll gjorde segregeringspraksisen ved bilbanen mer avslappet.

For å oppsummere, mener jeg at kvinners handlingsmuligheter påvirkes av en interseksjonalitet hvor blant annet klassetilhørighet påvirker hva kvinner kan og ikke kan gjøre. I Riyadh er sosiale konvensjoner mer fleksible blant eliten og i situasjoner hvor sosial kontroll er begrenset.

\section{Konklusjon}

Artikkelen har diskutert segregeringspraksisen ved offentlige fritidsarenaer i Riyadh. Kjønns- 
segregeringen kan sees på som en taktisk/organiserende makt, som påvirker individers muligheter i en konkret setting. Formingen av offentlige arenaer er gjort i samsvar med forestillinger om at ubeslektede menn og kvinner må holdes separert for å kontrollere seksualitet. Men kvinner kan benytte kreative tactics for å håndtere de restriksjonene som begrenser deres handlingsmuligheter. Dette fikk bl.a. sitt uttrykk da en kvinne prøvde en bikinitruse midt $i$ en butikk, noe som er et tydelig brudd med sosiale konvensjoner om tildekning og atferd foran ubeslektede menn. Empirien tegner et bilde av at eliten enklere kan bryte segregeringsreglene enn befolkningen ellers. I arrangementer forbeholdt de høyere sosiale lag er segregeringspraksisen mer avslappet, sammenliknet med arenaer hvor det religiøse politiet har tilgang. Med utgangspunkt i artikkelens empiri, har jeg argumentert for at faktorer som sosial kontroll og klasse har en betydning for segregeringspraksisen i Riyadh.

\section{$\bullet f \cdot$}

1 Samtlige kvinner i Saudi-Arabia må bruke abaya, en lang svart kappe som skjuler den kvinnelige kroppen. Abayaen trekkes enten over hodet eller kneppes opp foran.

2 Crenshaw, Kimberle: "Mapping the Margins: Intersectionality, Identity Politics, and Violence against Women of Color", i Stanford Law Review. vol 43 (6), 1991, s 1245 .

3 Altorki, Soraya: Women in Saudi Arabia. Ideology and behaviour among the elite. Colombia University Press: New York, 1986 // Yamani, Mai: Changed identities. The challenge of New Generation in Saudi Arabia. Royal Institute of International Affairs: London. 2000 // Al Khateeb, Salwa: "Male/Female Relationship in Pre-oil Saudi Family: ethnographic study" i Family Perspective. Vol 30 (2), 1996, s 203-219// Al Khateeb, Salwa: "Women, Family, and the Discovery of Oil in Saudi Arabia" i Marriage \& Family Review Vol 27(1/2), 1998, s 167-189 // Doumato, Elenaor A: "Gender, Monarchy, and National Identity in Saudi Arabia" i British Journal of Middle Eastern Studies. Vol 19(1), 1992, s 31-47.

4 Marcus, George: "Ethnography in/of the World System. The Emergence of Multi-Sited Ethnography" i Ethnography Through Thick \& Thin, Princeton University Press. 1995.

5 Billaud, Julie: Malay's Sisters: Women's Public Visibility in Post War/Reconstruction Afghanistan. European DPhil. University of Sussex, 2009, s 22.
6 For en grov skissering av det saudiske klassesystemet: Yamani, Mai: Changed Identities. The challenge of New Generation in Saudi Arabia. Royal Institute of International Affairs. London. 2000, s 153.

7 Dahl, Tove Stang: Den muslimske familie, Universitetsforlaget: Oslo, 1992, s 85 .

8 Mernissi, Fatima: Beyond the veil. Male-Female Dynamics in a Modern Muslim Family. Al Saqi Books: London, 1985.

9 Muttawa er offentlig kjent som Hai'a. På engelsk oversettes det til Committee for the Promotion of Virtue and Prevention of Vice (CPVPV). Til tross for at Hai'a er den offentlige termen, brukes muttawa ofte på folkemunne og derfor også i denne artikkelen.

10 Khulwa oversettes bedre med flere ord på norsk. Hans Wehr oversetter khulwa bl.a. som privacy, solitude, seclusion, isolation. Wehr, Hans: Arab-English Dictionary. The Hans Wehr Dictionary of Modern Written Arabic. Ed: Cowan, J. Milton. Spoken Language Services. USA, 1994.

11 Doumato, Eleanor A: "Getting Cod's Ear. Women, Islam, and Healing in Saudi Arabia and the Gulf", Colombia University Press: New York, 1999, s 14.

12 Le Renard, Amélie: "Only for women. Women, the state, and reform in Saudi Arabia" i Middle East Journal. Volume 62 (4), 2008, s 626

13 Douglas, Mary: Rent og urent: En analyse av forestillinger omkring urenhet og tabu, Pax, Oslo, 1997, s 50

14 Lindisfarne-Tapper, Nancy \& Ingham, Bruce (1997): "Languages of Dress in the Middle East" Richmond, Surrey, 1997, s 21.

15 Wolf, Eric: "Facing Power: Old Insights, New Questions" i R. Borofsky (ed.): Assessing Cultural Anthropology. McCraw-Hill Inc. New York, 1994, s 218.

16 Kjøpesentre med separate avdelinger for kvinner er unntaket.

17 De Certeau Michel: The Practice of Everyday Life. University of California Press: California, 1988, s 32.

18 En liknende tilnærming gjør Julie Billaud i sin analyse av afghanske kvinner, hvor hun argumenterer for at både direkte og indirekte utfordrende handlinger er tactics (Billaud 2009, s 40).

19 Macleod, Arlene: "Hegemonic Relations and Cender Resistance: The New Veiling as Accommodating Protest in Cairo" i Signs. Vol 17 (3), 1992, s 534.

20 Abu-Lughod, Lila: "Do Muslim women really need saving? Anthropological Reflections on Cultural Relativism and its Others" i American Anthropologist Vol 104 (3), 2002, s 785.

21 Le Renard, Amélie: "Young Urban Saudi Women's Transgressions of Official Rules and the Production of a New Social Group" i Journal of Middle East Women's Studies. Volume 9 (3), 2013, s 113.

22 Ibid: $s 128$.

23 Al Qasimi, Noor "Immodest Modesty: Accommodating Dissent and the 'Abaya-as-Fashion" I Journal of Middle East women's studies vol.6 (1), 2010, s 56.

24 Ibid s 69.

25 I Saudi-Arabia bruker mange menn en lang hvit kjortel kalt thobe, og et hvitt og rødt tørkle kalt shemagh/ghutra på hodet. 
26 For litteratur om ekteskap og ekteskapsinngåelse i SaudiArabia, se: Kjeldstadli, Tine Viung: Kvinner i Riyadh. En studie om muligheter og begrensninger for kvinner handlingsvalg. UiO. Oslo. 2010, s 71-86 // Le Renard, Amélie: A society of young women. Opportunities of Place, Power and Reform in Saudi Arabia. Standford University Press. California, 2014, s 68-72.

27 Turner, Victor: The Anthropology of Performance. PAJ: New York, 1988, s 102.

28 Ibid, s 26 .

29 Kapchan, Deborah: Gender on the Market. Moroccan Women and The Revoicing of Tradition. University of Pennsylvania Press: Philadelphia. 1996, s130.

30 Bourdieu Pierre: Language and Symbolic Power. Polity Press: Cambridge, 1997, s 117. 